not been obtained, but $a$ mere stenosis of the lacrymal passages. It is only in this way that erroneous conclusions can be avoided.

\title{
BIBLIOGRAPHY
}

1. Wallsberg.- “ Uber den Bau der Tränenwege der Haussäugetiere und des Menschen," Preisschrift, Rostock, 1876.

2. Ellenberger, W. - "Handbuch der vergleichenden mikroskopischen Anatomie der Haustiere," Berlin, Bd. 1, S. 542-547, 1906.

3. Chauveau, A. and Arloing, S.-"Traite d'anatomie comparée des animaux domestiques. Paris, 1905.

4. Schirmer.- " Mikroskopische Anatomie und Physiologie der Tränenwege." Graefe Saemisch Handbuch der gesamten Angenheilkunde. II Aufl., I Teil, 7 Kap.

5. Romer.- ' Experimentelle Untersuchungen über Infection vom Conjunctivalsack aus," Zeitschr. f. Hygiene, S, 294-328, 1899.

6. Krause, Dr. W.-Anatomie des Kaninchens, Leipzig, 1868.

\section{LUPUS OF THE LACRYMAL SAC}

BY

R. R. JAMES

LONDON

ASSISTANT OPHTHALMIC SURGEON, ST. GEORGE'S HOSPITAL,

\author{
AND \\ Lionel Culledge \\ LONDON
}

SURGEON TO THE NOSE AND THIROAT DEPARTMENT, ST, GEORGE'S HOSPITAL

Fuchs, in his text-book on ophthalmology, states that tuberculosis of the lacrymal sac may occur by extension, either from the conjunctival or nasal mucosa. The following case in which definite evidence of tuberculosis was found in the tissue removed from the nasal mucosa and from the region of the lacrymal sac seems worthy of record.

A female, aged 26 years, attended the eye out-patients under one of us (R.R.J.) at St. George's Hospital in the summer of 1923 for a lacrymal abscess which had burst on the left side; there was a history of epiphora of some weeks duration on each side, but the abscess had only formed on the left side one week before she presented herself for treatment. At this time there was found to be regurgitation from the right sac on pressure over it with the finger; the left side showed a discharging fistula surrounded by a large mass of granulation tissue; apart from this there was a peculiar appearance over the soft parts of the nose on each side. This was shiny, slightly reddened but not ulcerated, and the 
terminal part of the nose was slightly swollen and bulbous; the patient stated that her nose had been in this state for about a year. The interior of the nose was not inspected at this time, and expectant treatment was adopted, pressure and the regular use of an astringent lotion for the right side and hot fomentations for the left; later in the year she was admitted for excision of the sac and was seen by L.C. On admission, the fistula was found to be in much the same state as on her first visit and the interior of the nose was found to be completely blocked by large crusts so that no view could be obtained ; the Wassermann reaction was reported negative. It was decided to try and clear up the anterior nares before any operation was attempted and after a week's use of a nebula, the inside of the nose was so much improved that it was decided to operate. The diagnosis of lupus was made at the time of operation. Under general anaesthesia, the usual incision was made for removal of the sac; the knife entered a cavity in the region of the sac, the deeper parts of which were found to be full of granulation tissue of the characteristic apple jelly type; these were scraped away with a sharp spoon and a piece of tissue, which appeared to be mucous membrane from the wall of the sac, sent to the laboratory for pathological examination; the wound was covered with B.I.P.P. and was left open. An extensive ulcer was seen in the anterior nares reaching over the outer wall and on to the septum, a piece of this ulcer was removed and sent over for insertion into a guinea-pig; haemorrhage was rather free.

The pathological report was that the tissue removed was full of giant cell systems characteristic of tuberculosis, with added evidence of pyogenic infection.

Ten days later the wound in the region of the sac was treated with the electric cautery which was also passed down the nasal canal, and at the same time the cautery was applied freely to the ulcerating area inside the anterior nares. Since the last operation, the fistulous track in the region of the sac has closed completely and the state of the nose has improved very much; the patient has been sent to her home in the country to recuperate for a month and she has been warned to return at the end of that time for inspection. It is probable that the inside of the nose will have to be cauterized again before the disease is eradicated. At the time of writing, the guinea-pig is fairly well, but it has developed a couple of hard lumps in the left groin, near the site of inoculation ; it will be killed later*. In conclusion, we wish to express our thanks to Dr. E. L. Hunt for the report on the animal and to Dr. Robert Donaldson for the pathological report.

* When the animal was killed, it was found to be riddled with tuberculosis. 